\title{
The effect of fermented duckweed (Lemna minor) in feed on growth and nutritional quality of tilapia (Oreochromis niloticus)
}

\author{
VIVI ENDAR HERAWATI ${ }^{1, \bullet}$, PINANDOYO ${ }^{1}$, Y.S. DARMANTO², NURMANITA RISMANINGSIH ${ }^{3}$, \\ SETO WINDARTO ${ }^{1}$, OCKY KARNA RADJASA ${ }^{4}$ \\ ${ }^{1}$ Department of Aquaculture, Faculty of Fisheries and Marine Sciences, Universitas Diponegoro. Jl. Prof. H. Soedarto, S.H., Semarang 50275, Central \\ Java, Indonesia. Tel./fax.: +62-24-7474698, `email: viviendar23@ gmail.com \\ ${ }^{2}$ Department of Fishery Product Technology, Faculty of Fisheries and Marine Sciences, Universitas Diponegoro. Jl. Prof. H. Soedharto, S.H., Semarang \\ 50275, Central Java, Indonesia. \\ ${ }^{3}$ Department of Materials Chemistry, Graduate School of Engineering, Nagoya University. Furo-cho, Chikusa-ku, Nagoya 464-8603, Japan. \\ ${ }^{4}$ Department of Marine Sciences, Faculty of Fisheries and Marine Sciences, Universitas Diponegoro. Jl. Prof. H. Soedarto, S.H., Semarang 50275, \\ Central Java, Indonesia
}

Manuscript received: 31 March 2020. Revision accepted: 27 June 2020.

\begin{abstract}
Herawati VE, Pinandoyo, Darmanto YS, Rismaningsih N, Widarto S, Radjasa OK. 2020. The effect of fermented duckweed (Lemna minor) in feed on growth and nutritional quality of tilapia (Oreochromis niloticus). Biodiversitas 21: 3350-3358. One of the raw materials used for making tilapia fish feed is soybean meal. Soybean prices continue to rise and currently reach 4,500 rupiah/kg, so that alternative feed ingredients that are cheap and environmentally friendly need to be sought. Alternative feed ingredients that can be utilized in making feed, one of which is Lemna minor meal. Duckweed (Lemna minor) which has a high nutrient content, such as $23.47 \%$ crude protein, $3.99 \%$ crude fat, $29.92 \%$ crude fiber, $23.6 \%$ ash, and $19.02 \%$ nitrogen-free extract, will be the best candidate as an alternative feed ingredient. This study aims to find growth performance and nutritional quality of tilapia fed by different feed formulations using different amounts of fermented L. minor meal. The dosage treatments of feed with fermented L. minor meal are $0 \%$ (A), 2.5\% (B), 5\% (C), and 7.5\% (D). Feeding of tilapia using fermented L. minor meal has a significant effect $(P<0.05)$ on total feed consumption, feed utilization efficiency, protein efficiency ratio, and relative growth rate, and had no significant effect $(P>0.05)$ on survival rate. The results found that the best biomass weight, total feed consumption, feed utilization efficiency, relative growth rate, protein efficiency ratio, and survival rate value was in the treatment B (usage of $2.5 \%$ L. minor meal) which were $38.58 \mathrm{~g}$, $110.17 \mathrm{~g}$, $70.10 \%, 2.01 \%, 1.98 \%$, and $94.44 \%$, respectively. The best nutritional quality was in the treatment B (usage of $2.5 \% \mathrm{~L}$. minor meal) which was amino acid lysine, the highest value of amino acid lysine was $25.22 \%$ and the highest value of linoleic fatty acid was $4.37 \%$.
\end{abstract}

Keywords: Aquaculture, fermentation, Lemna minor, natural feed, tilapia

\section{INTRODUCTION}

The Nile tilapia (Oreochromis niloticus) is a freshwater fish that is easy to cultivate. Production continues to increase and quality of tilapia remains as an important commercial factor; therefore, feed is an important factor in increasing the production and quality of tilapia. In freshwater fish aquaculture, fish feed costs more than $50 \%$ of the production costs (Appenroth et al. 2018; Chakrabarti et al. 2018; Pramana et al. 2019). One of the raw materials used to produce tilapia fish feed is soybean meal. Soybean prices have continued to rise and currently, the price is 4,500 rupiah/kg (Handajani, 2011); therefore, alternative, inexpensive, and environment-friendly feed ingredients are needed. Several alternative feed ingredients may be used in the feed, one of which is duckweed (Lemna minor) meal. $L$. minor is a water weed that is rarely utilized but has a highprotein content.

Duckweed is a water weed that grows rapidly. The high productivity of Lemna sp. supports its use as an alternative feed or feed supplement. However, the use of Lemna sp. as a feed ingredient is constrained by the high amount of crude fiber, which reduces feed digestibility. Lemna spp. have great potential for use as feed because they are abundant in water. Additionally, their growth is fast and they can multiply with weights double their initial weight within 3-4 df. Duckweed can contain 28\%-43\% crude protein, $5 \%$ fiber (dry weight), and high concentrations of minerals, such as phosphorus and potassium, as well as xanthophylls and carotenes (del Carmen Flores-Miranda et al. 2015). Duckweed meal is known for its high nutritive value of as much as $40 \%$ and high-crude protein, depending on the aquaculture system (Sogbesan et al. 2015). The protein content of duckweed is relatively high, namely $20-30 \%$ (dry weight). Research on L. minor as a substitute for soybean meal by Solomon and Okomoda (2012) demonstrated that L. minor with high-protein content and amino acids based on the needs of the fish could be used to replace soybean meal in feed formulations in fish farms. L. minor can be a substitute feed ingredient for soybean meal to reduce production costs and provide high nutrients for tilapia rearing. The rapid growth rate coupled with the high-protein content $(41 \%-45 \%)$ is a unique property of duckweed, which may make it suitable for supplementation or substitution of other plant or animal protein in fish diets. Duckweed is an excellent alternative to the use of soybean meal and fish meal in fish feed (Sogbesan et al. 2015). 
One way to reduce the crude fiber content in Lemna is through a fermentation process. According to Virnanto et al. (2016), the fermentation process can reduce high crude fiber content. Additionally, fermentation can also increase the nutritional value of some ingredients. The goal of the fermentation process is to increase the content and quality of protein, maintain the nutritional value during storage, and reduce the anti-nutrient substances of the feed ingredients. The fermentation process can also increase the nutritional value of ingredients in the meal (Nwachi 2013). Fermentation is the anaerobic dissimilation process of organic compounds mediated by the activity of microorganisms or extracts from the cells of these microorganisms (Abu et al. 2013). The purpose of fermentation is to shorten the long chain of amino acids and fatty acids to facilitate the absorption of feed during metabolic processes using probiotic bacteria to enhance growth and enrich nutrients in the larval feed (Nwachi 2013). The advantages of the fermentation process include the ability to improve nutrients, especially proteins and fats, produce specially scented food, and increase energy efficiency and ease of use.

Consequently, given the high nutritional quality of $L$. minor and the continued increase in the price of soybean meal, in this study, we reported the substitution of soybean meal using fermented $L$. minor meal. The objective of this study was to determine the growth performance and nutritional quality of tilapia feed different formulations using different amounts of fermented L. minor meal $(0 \%$, $2.5 \%, 5 \%$, and $7.5 \%$ ). Furthermore, the best feed formulation among the treatments based on the results was determined.

\section{MATERIALS AND METHODS}

\section{Lemna minor meal fermentation}

Lemna minor plants were obtained from Lake Rawa Pening, Semarang, Indonesia. They were cleaned of dirt and dried in the sun. The method of drying L. minor was according to the research conducted by Solomon and Okomoda (2012), where drying was also conducted using sunlight. The dried leaves were then crushed and sieved. $L$. minor meal fermentation was performed by mixing the probiotic microorganisms Lactobacillus casei and Saccharomyces cerevisiae evenly with $L$. minor meal. The duckweed was washed, dried, and fermented using $1 \mathrm{~mL}$ of commercially available bacteria containing Lactobacillus casei and $S$. cerevisiae probiotic bacteria and molasses as an activator with a ratio of 1: 1 in $100 \mathrm{~mL}$ of water (Pinandoyo et al. 2019). The mixed product was then put in a plastic bag and stored at room temperature. The results of the fermentation of $L$, minor meal were indicated by an acidic odor. The next step was to open the plastic bag containing the fermented L. minor meal to allow cooling.

This research was conducted experimentally, using a completely randomized design (CRD) with four treatments with three replications. The treatments of this research were as follows: Treatment A: Feeding without fermented L. minor meal substitution $(0 \%)$, B: Feeding with fermented L. minor meal substitution (2.5\%), C. Feeding with fermented L. minor meal substitution (5\%), D:
Feeding with fermented L. minor meal substitution (7.5\%). Determination of the above dose refers to previous research, conducted by Solomon and Okomoda (2012) about the growth performance of tilapia fed by duckweed meal. The results of the research which was carried out using $L$. minor meal without fermentation process and got the best results at a dose of $5 \%$.

\section{Diet preparation}

The fermented L. minor meal was dried and the nutrient composition was tested. The test feed in this study was artificially pressed into the form of pellets using local ingredients, such as fish meal, soybean meal, L. minor meal, bran flour, wheat flour, cornstarch, fish oil, corn oil, vitamins, minerals, carboxymethylcellulose, and water. First, the feed was mixed with the lowest to the highest percentage concentration based on Table 2 and stirred until homogeneous. Then, warm water was added and constituted as much as $35 \%-40 \%$ of the total ingredients. The water was added while the ingredients were stirred until evenly distributed and smooth such that clumps could be formed using a mill and dried in an oven at a temperature of $<50^{\circ} \mathrm{C}$ until the water content of the feed was less than $10 \%$ of the initial water content.

\section{The nutritional quality of feed}

Proximate analysis was carried out for the dried feed. $L$. minor meal nutrient content before and after the fermentation process is presented in Table 1. Proximate analysis of feed formulations in the study is presented in Tables 1 and 2, respectively. The feed formulation using fermented L. minor meal as soybean meal substitution used in this study is presented in Table 2. The results of the Proximate analysis for each test feed used during the study are presented in Table 3.

\section{Water quality parameters}

Water quality parameters measured include Dissolved Oxygen (DO), $\mathrm{pH}$ value, temperature, and ammonia content. The data of temperature, DO, $\mathrm{pH}$, and ammonia are presented in Table 4.

\section{Essential amino acid profile analysis}

The amino acid composition of the sample was determined using High-performance liquid chromatography (HPLC) (Shimadzu LC-6A) (AOAC, 2000; and Herawati et al. 2014). The essential amino acid profile of $L$. minor was determined by examining its essential amino acid content. The essential amino acid analysis was conducted using an HPLC type 1100 with a Eurospher 100-5 C18, 250 x $4.6 \mathrm{~mm}$ column that has $\mathrm{P} / \mathrm{N}$ : $1115 \mathrm{Y} 535$ pre-column. The effluents were: A) $0.01 \mathrm{M}$ acetate buffer at $\mathrm{pH} 5.9$; and B) $0.01 \mathrm{M} \mathrm{MeOH}$ acetate buffer at $\mathrm{pH} 5.9$; THF> 80: 15: 5 $\Lambda$ Fluorescence: Ext: $340 \mathrm{~mm} \mathrm{Em} \mathrm{:} 450 \mathrm{~nm}$. About $2.5 \mathrm{~g}$ of the sample was put into a sealed glass. Then, $15 \mathrm{~mL}$ of $\mathrm{HCl}$ $6 \mathrm{~N}$ was added. The mixture was then vortexed for homogeneity and underwent hydrolysis using an autoclave at $110{ }^{\circ} \mathrm{C}$ for 12 hours before being cooled down to room temperature and neutralized with $\mathrm{NaOH} 6 \mathrm{~N}$. After the addition of $2.5 \mathrm{~mL}$ of $40 \%$ Lead Acetate and $1 \mathrm{~mL}$ of $15 \%$ 
oxalate acid, around $3 \mathrm{~mL}$ of the mixture was filtered with $0.45 \mu \mathrm{m}$ millex. For the injection into HPLC, $25 \mu \mathrm{L}$ of the filtered mixture plus $475 \mu \mathrm{L}$ of OPAA solution was vortexed and incubated for 3 minutes. Finally, $30 \mu \mathrm{L}$ of the final mixture was put into the HPLC (Herawati et al. 2014). Amino acid profile of feed using fermented L. minor meal for tilapia is presented in Table 5 .

Table 1. Proximate analysis results for Lemna minor meal before and after the fermentation process

\begin{tabular}{lccccc}
\hline \multirow{2}{*}{ Ingredients } & \multicolumn{5}{c}{ Components (\%) } \\
\cline { 2 - 6 } & Protein & NFE & Fat & Crude fiber & Ash \\
\hline L. minor meal & 23.47 & 19.02 & 3.99 & 29.92 & 23.6 \\
$\begin{array}{l}\text { Fermented } L . \\
\text { minor } \text { meal }\end{array}$ & 32.13 & 15.96 & 5.13 & 28.58 & 18.20
\end{tabular}

Note: Protein and ash had a significant effect; NFE, fat and crude fiber have no significant effect.

Table 2. Feed formulation using fermented Lemna minor meal as soybean meal substitution used in the study

\begin{tabular}{|c|c|c|c|c|}
\hline \multirow[b]{2}{*}{ Feed ingredients } & \multicolumn{4}{|c|}{ Feed $(\mathrm{g})$} \\
\hline & $\begin{array}{c}\mathrm{A} \\
(0 \%)\end{array}$ & $\begin{array}{c}\text { B } \\
(2.5 \%)\end{array}$ & $\begin{array}{c}C \\
(5 \%)\end{array}$ & $\begin{array}{c}\text { D } \\
(7.5 \%)\end{array}$ \\
\hline \multicolumn{5}{|l|}{ Ingredients (\% dry weight) } \\
\hline Fish meal & 32.86 & 32.78 & 32.71 & 32.64 \\
\hline Soybean meal & 33.89 & 31.99 & 30.07 & 28.18 \\
\hline L. minor meal & 0.00 & 2.74 & 5.46 & 8.17 \\
\hline Wheat flour & 6.85 & 7.79 & 6.89 & 3.83 \\
\hline Rice bran meal & 8.46 & 9.92 & 12.86 & 16.37 \\
\hline Cornstarch & 7.94 & 4.78 & 2.01 & 0.90 \\
\hline Fish oil & 2.00 & 2.00 & 2.00 & 2.00 \\
\hline Corn oil & 2.00 & 2.00 & 2.00 & 2.00 \\
\hline Vitamins-minerals mix* & 5.00 & 5.00 & 5.00 & 5.00 \\
\hline \multicolumn{5}{|l|}{ Carboxymethylcellulose } \\
\hline$(\mathrm{CMC})$ & 1.00 & 1.00 & 1.00 & 1.00 \\
\hline Total & 100,00 & 100,00 & 100,00 & 100,00 \\
\hline
\end{tabular}

Note: Calculation of feed formulations based on Proximate Composition and Analysis of Feed Materials used during research (\% Dry Weights) (Wilson 1982). * Vitamins-minerals mix (PT. Indosco Dwijayasakti, Surabaya, Indonesia) contained vitamin A, vitamin $\mathrm{D} 3$, vitamin $\mathrm{K} 3$, vitamin $\mathrm{E}$, vitamin $\mathrm{B}$ 1, vitamin $\mathrm{B}$ 2, vitamin $\mathrm{B} 6$, vitamin $\mathrm{B} 12$, vitamin $\mathrm{C}$, folic acid, biotin, inositol, nicotinamide, choline chloride, $\mathrm{Co}, \mathrm{Cu}, \mathrm{I}, \mathrm{Mn}, \mathrm{Se}$, and $\mathrm{Zn}$. This is a commercially vitamins-minerals mix; the quantity applied to the feed was 5 grams.

Table 3. Proximate composition of experimental diets used in the present study

\begin{tabular}{|c|c|c|c|c|}
\hline \multirow[b]{2}{*}{ Contents } & \multicolumn{4}{|c|}{ Feed (g) } \\
\hline & $\begin{array}{c}A \\
(0 \%)\end{array}$ & $\begin{array}{c}\text { B } \\
(2.5 \%)\end{array}$ & $\begin{array}{c}C \\
(5 \%)\end{array}$ & $\begin{array}{c}\mathrm{D} \\
(\mathbf{7 . 5 \%})\end{array}$ \\
\hline Protein $(\%)$ & 33.84 & 34.11 & 33.97 & 35.54 \\
\hline NFE (\%) & 14.65 & 11.87 & 15.45 & 6.79 \\
\hline Fat (\%) & 8.94 & 8.43 & 7.73 & 8.65 \\
\hline Energy (kcal) * & 262.23 & 259.38 & 255.75 & 251.98 \\
\hline $\mathrm{E} / \mathrm{P}$ ratio $* *$ & 8.74 & 8.65 & 8.52 & 8.40 \\
\hline Fiber $(\%)$ & 24.37 & 25.14 & 22.57 & 25.83 \\
\hline Ash (\%) & 18.20 & 20.45 & 20.28 & 23.19 \\
\hline
\end{tabular}

Note: * Based on the calculation of DE (digestible energy) with the assumption for protein $=3.5 \mathrm{kcal} / \mathrm{g}$, fat $=8.1 \mathrm{kcal} / \mathrm{g}$, Nitrogenfree extract $(\mathrm{NFE})=2.5 \mathrm{kcal} / \mathrm{g}$ (Wilson 1982). ** E/P values for the optimal growth of fish ranged from 8-12 kcal/g (De Silva, 1987)
Table 4. Water quality parameter measurement results of tilapia (Oreochromis niloticus) aquaculture media during the study

\begin{tabular}{lcc}
\hline $\begin{array}{c}\text { Water quality } \\
\text { parameters }\end{array}$ & $\begin{array}{c}\text { Range of water } \\
\text { quality parameter }\end{array}$ & $\begin{array}{c}\text { References } \\
\text { (feasibility) }\end{array}$ \\
\hline Temperature $\left({ }^{\circ} \mathrm{C}\right)$ & $25-28$ & $25-32$ \\
$\mathrm{pH}$ & $7.0-7.5$ & $6.0-8.5$ \\
$\mathrm{DO}(\mathrm{mg} / \mathrm{L})$ & $3.00-3.60$ & $\geq 3$ \\
$\mathrm{NH}_{3}(\mathrm{mg} / \mathrm{L})$ & $0.0028-0.0437$ & $<0.02$ \\
Salinity & 0.00 & 0.00 \\
\hline Reference: &
\end{tabular}

Reference: Asadi et al. 2012; Solomon dan Okomoda (2012)

Table 5. Amino acid profile of feed using fermented Lemna minor meal for tilapia (Oreochromis niloticus)

\begin{tabular}{lrccc}
\hline $\begin{array}{l}\text { Amino acid } \\
\text { profile (\%) }\end{array}$ & $\begin{array}{c}\mathbf{A} \\
\mathbf{( 0 \% )}\end{array}$ & $\begin{array}{c}\mathbf{B} \\
\mathbf{( 2 . 5 \% )}\end{array}$ & $\begin{array}{c}\mathbf{C} \\
\mathbf{( 5 \% )}\end{array}$ & $\begin{array}{c}\mathbf{D} \\
\mathbf{( 7 . 5 \% )}\end{array}$ \\
L-Histidine & $1.8 \pm 0.01$ & $5.5 \pm 0.05$ & $3.8 \pm 0.05$ & $4.2 \pm 0.05$ \\
L-Serine & $1.5 \pm 0.03$ & $4.6 \pm 0.02$ & $2.7 \pm 0.02$ & $3.1 \pm 0.02$ \\
L-Arginine & $2.6 \pm 0.05$ & $5.8 \pm 0.06$ & $3.4 \pm 0.06$ & $2.9 \pm 0.06$ \\
Glycine & $1.4 \pm 0.04$ & $4.7 \pm 0.09$ & $2.9 \pm 0.09$ & $2.1 \pm 0.09$ \\
L-Aspartic acid & $2.9 \pm 0.08$ & $4.3 \pm 0.04$ & $2.7 \pm 0.04$ & $4.6 \pm 0.04$ \\
L-Glutamic acid & $1.5 \pm 0.09$ & $3.6 \pm 0.02$ & $1.9 \pm 0.02$ & $1.2 \pm 0.02$ \\
L-Threonine & $3.5 \pm 0.03$ & $5.25 \pm 0.08$ & $2.8 \pm 0.08$ & $3.4 \pm 0.08$ \\
L-Alanine & $3.5 \pm 0.06$ & $5.89 \pm 0.03$ & $4.9 \pm 0.03$ & $3.7 \pm 0.03$ \\
L-Proline & $0.7 \pm 0.04$ & $3.8 \pm 0.09$ & $2.9 \pm 0.09$ & $2.3 \pm 0.09$ \\
L-Cystine & $0.3 \pm 0.01$ & $2.4 \pm 0.07$ & $0.6 \pm 0.07$ & $2.1 \pm 0.07$ \\
L-Lysine & $1.9 \pm 0.02$ & $5.8 \pm 0.03$ & $2.5 \pm 0.03$ & $3.9 \pm 0.03$ \\
L-Tyrosine & $2.4 \pm 0.03$ & $4.9 \pm 0.05$ & $1.8 \pm 0.05$ & $0.7 \pm 0.05$ \\
L-Methionine & $0.4 \pm 0.04$ & $5.4 \pm 0.06$ & $2.2 \pm 0.06$ & $1.7 \pm 0.06$ \\
L-Valine & $1.8 \pm 0.05$ & $3.7 \pm 0.04$ & $2.1 \pm 0.04$ & $2.4 \pm 0.04$ \\
L-Isoleucine & $2.6 \pm 0.08$ & $6.7 \pm 0.02$ & $2.6 \pm 0.02$ & $3.9 \pm 0.02$ \\
L-Leucine & $3.1 \pm 0.05$ & $9.2 \pm 0.08$ & $1.9 \pm 0.08$ & $2.7 \pm 0.08$ \\
L-Phenylalanine & $3.6 \pm 0.04$ & $5.2 \pm 0.09$ & $4.5 \pm 0.09$ & $4.3 \pm 0.09$ \\
Tryptophan & $0.1 \pm 0.01$ & $2.3 \pm 0.05$ & $0.9 \pm 0.05$ & $5.9 \pm 0.05$ \\
\hline
\end{tabular}

\section{Fatty acid profile analysis}

The fatty acid composition of the sample was determined using a gas chromatograph (Shimadzu) (AOAC 2000; and Herawati et al. 2014). The fatty acid profile of $L$. minor can be determined by analyzing its total fatty acid content. The equipment used for this purpose was a Gas Chromatograph (GCMS) QP-2010 and the Mass Spectrophotometer with a W Cot fused Silica Counting CPSIL-88 column of $50 \mathrm{~m}$ length, $0.22 \mathrm{~mm}$ diameter and at a column temperature of $120-200^{\circ} \mathrm{C}$. The method employed was in situ transesterification. $100 \mathrm{mg}$ of L. minor sample was homogenized using $4 \mathrm{~mL}$ of water. The resulting 100 $\mu \mathrm{L}$ homogenate was then transferred into a reaction tube. One hundred $\mu \mathrm{L}$ of methylene chloride was then added, along with $1 \mathrm{~mL}$ of $\mathrm{NaOH} 0.5 \mathrm{~N}$ in methanol. Once nitrogen was added and the tube was sealed, it was heated to $90{ }^{\circ} \mathrm{C}$ for 10 minutes. The reaction tube was then cooled, and $1 \mathrm{~mL}$ of $14 \% \mathrm{BF}_{3}$ in methanol was added. After the nitrogen addition, heating ensued at the same temperature for the next 10 minutes. Afterward, the reaction tube was cooled to ambient temperature, and $1 \mathrm{~mL}$ of water and 200$500 \mu \mathrm{L}$ of hexane were added. The mixture was then vortexed for $1 \mathrm{~min}$ to extract the fatty acids methyl ester. After centrifugation, the upper layer of the sample was ready for GC analysis (Herawati et al, 2014). Fatty acid 
profile of feed using fermented L. minor meal as a meal for tilapia is presented in Table 6 .

\section{Feeding of nile tilapia}

Nile tilapia (O. niloticus) obtained from the Siwarak Fish Seed Center, Semarang District, Indonesia. The tested fish seed, which was used, had an average weight of $5.40 \pm$ $0.06 \mathrm{~g} / \mathrm{fish}$. The initial average weight was measured to obtain homogenous initial data. Furthermore, the initial weight is needed to measure the final weight and weight gain during the study. The rearing container used in this study is a 30 Liter capacity plastic bucket as a rearing container filled with 20 Liters of water with a stocking density of $1 \mathrm{fish} / \mathrm{L}$. The bucket is closed with waring so that the test fish does not jump out of the container (Handajani 2011). The method of feeding was using at satiation method (fed as much as they could consume each day) with the frequency of feeding three times a day at the morning (08:00), noon (12:00), and afternoon (16:00) of Western Indonesia Time (Srirangam 2016; Pinandoyo et al. 2019).

\section{Data calculations and analysis}

On the $45^{\text {th }}$ day of feeding, fish in each container were weighed and counted. The weighing was based on each treatment and replication. The parameters measured include the total feed consumption (TFC), efficiency of feed utilization (FUE), protein efficiency ratio (PER), relative growth rate (RGR) and survival rate (SR). The total feed consumption and relative growth rate can be calculated using the Tacon (1987).

Data in the form of percentages include feed utilization efficiency (FUE), protein efficiency ratio (PER), relative growth rate (RGR) and survival rate (SR), arcsin data transformation, normality test, homogeneity test, and additivity test are carried out to ensure that data is normal, homogeneous and additive. Data were analyzed using ANOVA to see the effect. Duncan's multiple range test was conducted to determine the differences between treatments. The proximate composition of the samples was determined using a standard procedure (AOAC, 2000; Herawati et al. 2015).

\section{RESULTS AND DISCUSSION}

\section{Results}

The study of giving feed to tilapia using fermented $L$. minor meal as a substitute for soybean meal gave results in the form of biomass weight, relative growth rate (RGR), total feed consumption value (TFC), protein efficiency ratio (PER), feed utilization efficiency (FUE), and survival rate (SR). The results showed that feeding using fermented L. minor meal had a significant effect $(\mathrm{P}<0.05)$ on TFC, FUE, PER and RGR and did not have a significant effect ( $\mathrm{P}$ $>0.05)$ on SR. The results of the study on the growth of tilapia fed by L. minor meal are presented in Table 7 .

The results of the study found that the best value of biomass weight, TFC, FUE, RGR, PER, and SR is at the treatment of tilapia which was fed using $2.5 \%$ of fermented L. minor meal as a substitute for soybean meal (B), they are $38.58 \mathrm{~g} \pm 0.08 ; 110.17 \mathrm{~g} \pm 3.11 ; 70.10 \% \pm 0.07 ; 2.01 \% \pm$ $0.05 ; 1.98 \% \pm 0.04 ; 94.44 \% \pm 0.70$ respectively, while the lowest value was in tilapia fed by using $0 \%$ of fermented $L$. minor meal as a substitute for soybean meal (A), they are $23.05 \mathrm{~g} \pm 0.05 ; 88.17 \mathrm{~g} \pm 2.11 ; 52.14 \% \pm 0.47 ; 1.15 \% \pm$ $0.02 ; 1.35 \% \pm 0.08 ; 88.00 \% \pm 0.67$. The amino acid profile of tilapia fed by fermented L. minor meal as a substitute for soybean meal is presented in Table 8 .

Based on the analysis results, the highest amino acid profile is at tilapia fed by fermented $L$. minor meal as a substitute for soybean meal with a $2.5 \%$ formulation and found at lysine, which is $25.22 \%$ in essential amino acids and arginine is $10.35 \%$ in non-essential amino acids. The fatty acid profile of tilapia fed by fermented $L$. minor as a substitute for soybean meal is presented in Table 9.

The analysis results of the highest fatty acid profile in tilapia fed by $2.5 \%$ of fermented L. minor meal as a substitute soybean meal were found in linolenic fatty acids which are $18.96 \%$ in essential fatty acids, and palmitic fatty acids which are $7.59 \%$ in non-essential fatty acids.

Table 6. Fatty acid profile of feed using fermented Lemna minor meal for tilapia (Oreochromis niloticus)

\begin{tabular}{|c|c|c|c|c|}
\hline Fatty acid profile (\%) & $\mathrm{A}(\mathbf{0 \%})$ & B $(2.5 \%)$ & $\mathrm{C}(5 \%)$ & D $(7.5 \%)$ \\
\hline Myristic & $0.49 \pm 0.04$ & $0.48 \pm 0.09$ & $0.41 \pm 0.02$ & $0.50 \pm 0.05$ \\
\hline Pentadecanoic & $0.18 \pm 0.06$ & $0.15 \pm 0.08$ & $0.17 \pm 0.04$ & $0.08 \pm 0.02$ \\
\hline Palmitic & $2.29 \pm 0.08$ & $2.59 \pm 0.04$ & $1.97 \pm 0.08$ & $2.12 \pm 0.01$ \\
\hline Stearic & $1.65 \pm 0.02$ & $2.91 \pm 0.09$ & $0.52 \pm 0.03$ & $2.08 \pm 0.05$ \\
\hline Oleic/ $\omega 9$ & $0.95 \pm 0.03$ & $3.21 \pm 0.01$ & $0.89 \pm 0.08$ & $0.55 \pm 0.03$ \\
\hline Linoleic/ $\omega 6$ & $0.46 \pm 0.07$ & $4.37 \pm 0.02$ & $1.09 \pm 0.07$ & $0.75 \pm 0.02$ \\
\hline Linolenic/ $\omega 3$ & $0.08 \pm 0.09$ & $3.32 \pm 0.01$ & $0.39 \pm 0.03$ & $0.56 \pm 0.07$ \\
\hline Arachidic & $2.83 \pm 0.02$ & $3.05 \pm 0.03$ & $1.02 \pm 0.04$ & $1.25 \pm 0.05$ \\
\hline Arachidonic & $0.15 \pm 0.05$ & $0.13 \pm 0.08$ & $0.15 \pm 0.02$ & $0.06 \pm 0.08$ \\
\hline Eicosapentaenoic & $2.62 \pm 0.08$ & $3.58 \pm 0.04$ & $2.83 \pm 0.02$ & $3.17 \pm 0.01$ \\
\hline $\mathrm{AA}$ & $0.15 \pm 0.04$ & $0.13 \pm 0.07$ & $0.15 \pm 0.09$ & $2.18 \pm 0.03$ \\
\hline Docosa-hexaenoic acid (DHA) & $0.08 \pm 0.04$ & $1.07 \pm 0.03$ & $0.07 \pm 0.01$ & $0.39 \pm 0.08$ \\
\hline EPA & $0.53 \pm 0.02$ & $1.52 \pm 0.06$ & $1.50 \pm 0.07$ & $1.09 \pm 0.02$ \\
\hline
\end{tabular}


Table 7. Growth of tilapia fed by fermented Lemna minor meal

\begin{tabular}{lcccc}
\hline \multirow{2}{*}{ Parameters } & \multicolumn{3}{c}{ Treatments } \\
\cline { 2 - 5 } & A (0\%) & B (2.5\%) & C (5\%) & D (7.5\%) \\
\hline Initial Body Weight (IBW) (g) & $5.40 \pm 0.03^{\mathrm{a}}$ & $5.55 \pm 0.08^{\mathrm{a}}$ & $5.50 \pm 0.04^{\mathrm{a}}$ & $5.55 \pm 0.05^{\mathrm{a}}$ \\
Final Body Weight (FBW) (g) & $23.05 \pm 0.05^{\mathrm{a}}$ & $38.58 \pm 0.08^{\mathrm{b}}$ & $33.67 \pm 0.02^{\mathrm{b}}$ & $30.01 \pm 0.06^{\mathrm{b}}$ \\
Weight Gain (WG) (g) & $17.65 \pm 0.12^{\mathrm{a}}$ & $33.03 \pm 0.11^{\mathrm{b}}$ & $28.17 \pm 0.15^{\mathrm{b}}$ & $24.46 \pm 0.17^{\mathrm{b}}$ \\
RGR (\%) & $1.15 \pm 0.02^{\mathrm{a}}$ & $2.01 \pm 0.05^{\mathrm{b}}$ & $1.48 \pm 0.04^{\mathrm{b}}$ & $1.74 \pm 0.09^{\mathrm{b}}$ \\
TFC (g) & $88.17 \pm 2.11^{\mathrm{a}}$ & $110.17 \pm 3.11^{\mathrm{b}}$ & $98.11 \pm 3.19^{\mathrm{b}}$ & $95.13 \pm 3.10^{\mathrm{b}}$ \\
PER (\%) & $1.35 \pm 0.08^{\mathrm{a}}$ & $1.98 \pm 0.04^{\mathrm{a}}$ & $1.66 \pm 0.06^{\mathrm{a}}$ & $1.47 \pm 0.05^{\mathrm{a}}$ \\
FUE (\%) & $52.14 \pm 0.47^{\mathrm{a}}$ & $70.10 \pm 0.07^{\mathrm{b}}$ & $65.82 \pm 0.05^{\mathrm{b}}$ & $63.38 \pm 0.06^{\mathrm{b}}$ \\
SR (\%) & $88.00 \pm 0.67^{\mathrm{a}}$ & $94.44 \pm 0.70^{\mathrm{a}}$ & $90.20 \pm 0.12^{\mathrm{a}}$ & $90.20 \pm 0.70^{\mathrm{b}}$ \\
\hline
\end{tabular}

Note: ${ }^{\mathrm{a}}$ : the value was not significantly different. ${ }^{\mathrm{b}}$ : the value was significantly different

Table 8. Amino acid profile of tilapia (Oreochromis niloticus) fed by using fermented Lemna minor meal

\begin{tabular}{lcccc}
\hline Amino acid profile $(\boldsymbol{\%})$ & $\mathbf{A}(\mathbf{0 \% )}$ & $\mathbf{B}(\mathbf{2 . 5 \% )}$ & $\mathbf{C ~ ( 5 \% )}$ & $\mathbf{D}(\mathbf{7 . 5 \% )}$ \\
\hline L-Histidine & $3.14 \pm 0.03$ & $3.52 \pm 0.03$ & $3.85 \pm 0.05$ & $4.92 \pm 0.08$ \\
L-Serine & $1.40 \pm 0.07$ & $2.63 \pm 0.07$ & $2.76 \pm 0.02$ & $5.61 \pm 0.03$ \\
L-Arginine & $8.39 \pm 0.02$ & $10.35 \pm 0.05$ & $9.36 \pm 0.07$ & $8.61 \pm 0.04$ \\
Glycine & $1.48 \pm 0.05$ & $3.78 \pm 0.09$ & $5.33 \pm 0.02$ & $6.36 \pm 0.04$ \\
L-Aspartic acid & $8.25 \pm 0.09$ & $4.70 \pm 0.07$ & $5.65 \pm 0.03$ & $6.13 \pm 0.03$ \\
L-Glutamic acid & $1.76 \pm 0.05$ & $2.89 \pm 0.04$ & $2.85 \pm 0.07$ & $2.51 \pm 0.04$ \\
L-Threonine & $3.37 \pm 0.09$ & $5.56 \pm 0.03$ & $5.47 \pm 0.07$ & $4.02 \pm 0.09$ \\
L-Alanine & $3.21 \pm 0.02$ & $2.98 \pm 0.05$ & $3.51 \pm 0.01$ & $4.65 \pm 0.05$ \\
L-Proline & $1.98 \pm 0.07$ & $3.44 \pm 0.04$ & $3.08 \pm 0.09$ & $2.25 \pm 0.05$ \\
L-Cystine & $5.74 \pm 0.04$ & $5.13 \pm 0.02$ & $2.72 \pm 0.03$ & $3.24 \pm 0.05$ \\
L-Lysine & $10.14 \pm 0.05$ & $25.22 \pm 0.05$ & $10.89 \pm 0.06$ & $13.92 \pm 0.08$ \\
L-Tyrosine & $2.86 \pm 0.06$ & $3.99 \pm 0.03$ & $3.59 \pm 0.06$ & $3.57 \pm 0.04$ \\
L-Methionine & $5.95 \pm 0.09$ & $2.20 \pm 0.07$ & $7.87 \pm 0.02$ & $5.97 \pm 0.03$ \\
L-Valine & $10.10 \pm 0.04$ & $4.46 \pm 0.07$ & $5.45 \pm 0.05$ & $5.44 \pm 0.05$ \\
L-Isoleucine & $5.62 \pm 0.03$ & $3.97 \pm 0.05$ & $5.41 \pm 0.07$ & $5.49 \pm 0.07$ \\
L-Leucine & $5.82 \pm 0.01$ & $4.40 \pm 0.05$ & $6.85 \pm 0.05$ & $5.10 \pm 0.08$ \\
L-Phenylalanine & $10.40 \pm 0.05$ & $6.43 \pm 0.07$ & $5.00 \pm 0.02$ & $5.61 \pm 0.03$ \\
Tryptophan & $10.39 \pm 0.03$ & $5.35 \pm 0.01$ & $7.36 \pm 0.05$ & $6.61 \pm 0.03$ \\
\hline
\end{tabular}

Table 9. Fatty acid profile of tilapia (Oreochromis niloticus) fed by using fermented Lemna minor meal as a substitute for soybean meal

\begin{tabular}{|c|c|c|c|c|}
\hline Fatty acid profile (\%) & $\mathrm{A}(0 \%)$ & B $(2.5 \%)$ & $\mathrm{C}(5 \%)$ & $\mathrm{D}(7.5 \%)$ \\
\hline Myristic & $1.49 \pm 0.04$ & $4.41 \pm 0.09$ & $1.82 \pm 0.02$ & $2.01 \pm 0.05$ \\
\hline Pentadecanoic & $2.81 \pm 0.06$ & $3.75 \pm 0.08$ & $2.36 \pm 0.04$ & $2.38 \pm 0.02$ \\
\hline Palmitic & $4.29 \pm 0.08$ & $7.59 \pm 0.04$ & $5.97 \pm 0.08$ & $6.12 \pm 0.01$ \\
\hline Stearic & $2.35 \pm 0.02$ & $4.71 \pm 0.09$ & $3.08 \pm 0.03$ & $2.01 \pm 0.05$ \\
\hline Oleic/ $\omega 9$ & $1.78 \pm 0.03$ & $8.90 \pm 0.01$ & $5.76 \pm 0.08$ & $4.16 \pm 0.03$ \\
\hline Linoleic/ $\omega 6$ & $4.65 \pm 0.07$ & $10.05 \pm 0.02$ & $7.83 \pm 0.07$ & $6.30 \pm 0.02$ \\
\hline Linolenic/ $\omega 3$ & $3.38 \pm 0.09$ & $18.96 \pm 0.01$ & $12.77 \pm 0.03$ & $13.43 \pm 0.07$ \\
\hline Arachidic & $2.83 \pm 0.02$ & $3.05 \pm 0.03$ & $1.02 \pm 0.04$ & $1.25 \pm 0.05$ \\
\hline Arachidonic & $0.15 \pm 0,05$ & $0.13 \pm 0,08$ & $0.15 \pm 0.02$ & $0.06 \pm 0,08$ \\
\hline Eicosapentaenoic & $2.53 \pm 0.09$ & $5.52 \pm 0.06$ & $3.50 \pm 0.04$ & $3.98 \pm 0.02$ \\
\hline AA & $1.65 \pm 0.04$ & $3.19 \pm 0.07$ & $2.15 \pm 0.09$ & $2.38 \pm 0.03$ \\
\hline Docosa-hexaenoic acid (DHA) & $4.15 \pm 0.04$ & $5.07 \pm 0.03$ & $4.17 \pm 0.01$ & $3.35 \pm 0.08$ \\
\hline EPA & $1.53 \pm 0.02$ & $3.87 \pm 0.06$ & $2.53 \pm 0.07$ & $2.19 \pm 0.02$ \\
\hline
\end{tabular}

\section{Discussion}

The present study demonstrated that $2.5 \%$ fermented $L$. minor meal as a substitution in fish feed resulted in the best growth performance of tilapia. This was because feed that was made at a dose of $2.5 \%$ had a texture and smell that were preferred by tilapia. This was shown by the results of research on weight gain $(33.03 \mathrm{~g})$ and the highest relative growth rate $(2.01 \%)$. The smell of the feed was caused by the amino acid glycine. The content of glycine in treatment $\mathrm{B}$ feed was higher than that in the other treatments. The function of the amino acid glycine is a natural attractant in L. minor meal that is used as a source of vegetable protein. This was reinforced by the results reported by Yilmaz (2004) and Khasani (2013), who found that glycine was a 
natural attractant found in sources of animal and vegetable protein. The relative growth performance of tilapia fed with $2.5 \%$ fermented L. minor meal resulted in better nutritional balance compared to that of the other treatment compositions. The feed in this treatment was consumed more compared to the feed in other treatments. This was because of the increased feed palatability. The use of $2.5 \%$ L. minor meal resulted in better feed utilization compared to that of soybean meal. This was supported by a study conducted by Khasani (2013), which stated that highquality artificial feed has a high level of palatability. Fish respond quickly to feed that have compounds that stimulate their sense of smell because of their chemoreceptor mechanism.

The use of different protein sources in combination can prevent a high inclusion level of any single anti-nutritional factor in the diet and can also be a means of compensating for an essential amino acid deficiency in any single protein source (Hossain and Jauncey, 1990). This is because feed containing L. minor meal has a high protein content, especially amino acids, and fatty acids, which are suitable for the nutritional needs of tilapia; thus, it can support the growth of tilapia. The utilization of protein in tilapia decreased with increasing levels of $L$. minor meal fermentation in the feed. This was confirmed by a study conducted by Olaniyi and Oladunjoye (2012), which stated that protein utilization decreased progressively with increasing levels of substitution of Lemna sp. in the feed. This research showed that increasing the composition of $L$. minor meal fermentation yielded lower values for growth and increases in biomass. The lysine content in feed was almost the same as the amino acid requirements for lysine by tilapia. According to Santiago and Lovell (1988), the need for lysine by tilapia (O. niloticus) is $5.12 \%$. The results showed the content of lysine and leucine were highest in treatment $\mathrm{B}$, namely $5.8 \%$ lysine and $9.8 \%$ leucine. According to Dewanji (1993), Lemna sp. is generally rich in leucine and lysine. When compared to soybean protein, Lemna sp. protein is higher in amino acid content. The results of this study were reinforced by the findings of Ovie and Eze (2013); if the feed contains the right amount of essential amino acids needed by fish species, the ideal protein for the species is fulfilled such that there is no lack or excess of amino acids. The growth rate was directly proportional to the value of efficiency of feed utilization such that the high efficiency of feed utilization resulted in relatively high growth rates. The higher the use of fermented L. minor meal as a substitution for soybean meal in this study, the greater the decrease in fish growth rate because of the low amino acid profile between these feed ingredients. Those responsible were the amino acids lysine and leucine in the feed, which could improve growth and nutritional quality. The results of the study were reinforced by the results reported by Ilyas (2014), which stated that the addition of L. perpusilla at a dose of $100 \%$ in tilapia feed showed the lowest growth rate compared to that of other treatments. Olaniyi and Oladunjoye (2012) also reported that the addition of $L$. minor meal, with as much as $100 \%$, to the feed of tilapia, showed the lowest growth results among the treatments.
The results of this study agreed with those of Srirangam (2016), which stated that increasing levels of protein, especially amino acids, could be accomplished by the fermentation process. During the fermentation process, there is an increase in the amount of nitrogen, with the increase caused by the activity of protease enzymes that break down proteins, such that they are more soluble in water. This resulted in an increase in the amino acid content of tilapia after being fed with fermented L. minor meal as a substitute for soybean meal. The fermentation process also aimed to increase the growth of tilapia by increasing the nutrients in the feed and facilitating the optimal absorption of the feed nutrients. Olaniyi and Oladunjoye (2012) stated that the fermentation process was not only able to reduce the high crude fiber content, but could also increase the nutritional value of the feed ingredients. Nwachi (2013) and Abu et al. (2013) stated that the purpose of fermentation was to increase the number of microorganisms and intensify their metabolism in feed, thereby producing new feed products with microorganisms to increase growth rates and enrich nutrients in larval feed. When the L. minor meal was not subjected to the fermentation process, the feed was difficult to digest by tilapia and had low nutrient content. The fermentation process is a biochemical process caused by microorganisms that occur enzymatically. Enzymes that work during the fermentation process can cause changes in feed ingredients. Changes that occur can be in the form of taste, color, shape, calories, and other properties. Asadi et al. (2012) stated that the function of fermentation was to contribute to the digestive enzymes of the fish and the absorption of organic material mediated by probiotics. Nwachi (2013), in his research, explained the function of probiotics in aquaculture, as increasing fish immunity to pathogens and significantly contributing to fish digestive enzymes.

The results showed that the fermentation process could improve the protein quality of the duckweed meal, as observed in the protein efficiency ratio (PER). However, it is important to note that in addition to their role in fermentation, bacteria are an important source of up to $70 \%$ high-quality protein (Aas et al. 2006a, b). In addition to high nutritional quality, the feed of tilapia using fermented L. minor meal as a substitute for soybean meal has a better level of feed palatability than that exhibited by other treatments; thus, it was highly preferred by the fish for consumption. Khasani (2013), Paul (2013), and Talukdar (2012) stated that high-quality artificial feed had a high level of palatability. In addition to higher nutritional quality, tilapia feed with $2.5 \%$ fermented L. minor as a substitute for soybean meal also had better taste than that exhibited by other treatments. This affects the choice of feed preferred by fish and feeds consumption considerably. Accordingly, it gives a higher PER yield compared to other treatments. This statement was reinforced by the results of Khasani (2013), Paul (2013), and Talukdar (2012), which stated that high-quality artificial feed has a high level of deliciousness.

Fish respond quickly to feed that has compounds that stimulate their sense of smell because of their 
chemoreceptor mechanism. These compounds are known as attractants. Olaniyi and Oladunjoye (2012) stated in their study that the addition of L. minor to tilapia feed resulted in high feed utilization values. The PER is influenced by the ability of fish to digest feed. Several factors influence this ability, one of which is the composition of feed, where the higher the protein used by the body, the higher the value of protein efficiency. Based on the results of this study, the highest PER value was in tilapia fed with $2.5 \%$ of fermented L. minor meal, apparently because of the energy and nutrient content in the feed being suitable for the needs of the tilapia. The amino acid content in the feed satisfied the needs of the tilapia. The lysine content in this study for the $2.5 \%$ L. minor meal was $5.8 \%$. This is higher than that of the lysine amino acid requirements for tilapia. According to Santiago and Lovell (1988), the need for lysine amino acids by tilapia is $5.12 \%$. The results showed that the PER in this study was higher than that in previous studies. The PER for the $2.5 \%$ L. minor in addition to the feed of tilapia was $1.98 \%$ compared to the PER of $0 \% \mathrm{~L}$. minor, which was $1.35 \%$ (Solomon and Okomoda, 2012). The highest PER values were for the treatment with $0 \%$ and $25 \%$ concentration of $L$. minor in tilapia feed, having a value of $0.88 \%$ (Olaniyi and Oladunjoye, 2012). The difference in PER values in this study compared to that in previous studies was caused by differences in the protein content of $L$. minor meal. The difference in protein content was in agreement with that reported by Salomon and Okomoda (2012), which stated that it was caused by differences in the type of $L$. minor and nutritional availability in the areas where they were cultivated.

The difference in protein content is thought to be caused by differences in the type of L. minor and their origin. This was confirmed by the results reported by Salomon and Okomoda (2012), who stated that the differences in results were caused by differences in the type of L. minor and nutritional availability in the areas where they were cultivated.

The nutritional quality of tilapia feed with fermented $L$. minor meal instead of soybean meal based on the analysis of amino acids and fatty acids showed that the best value was $2.5 \%$ L. minor, as shown in Tables 5 and 6 . In this study, the best value was the $2.5 \%$ formulation (Table 8 ) for lysine $(45.22 \%)$ and arginine $(74.35 \%)$. This was in agreement with the results reported by Asadi et al. (2012), wherein the protein of Lemna sp. was generally rich in leucine and lysine. Compared to soybean protein, the protein in duckweed had a higher amino acid content. Amino acids are widely used for body maintenance, health, and synthesis of new structures from new structural proteins that will produce maximum feed efficiency and growth. The high amino acid content in feed with $2.5 \% \mathrm{~L}$. minor meal fermentation compared to that in other feeding treatments can better meet the amino acid requirements of tilapia, which is $5.12 \%$. Fish that continue to grow will only use a small amount of the amino acids for energy. The amino acid lysine serves to increase growth and provide an energy source because lysine aids in the production of carnitine, which decomposes the source of nutrients in food into fatty acids. This statement is in agreement with the results reported by Ovie and Eze (2013), Valverde et al. (2013), and Herawati et al. (2015), which stated that the amino acid lysine serves as a framework for vitamin B1 formation, anti-viral immunity, aids in calcium absorption, stimulates appetite, and helps in the production of carnitine, which converts fatty acids into energy.

Based on the results of this study, the highest fatty acid profile was for linoleic fatty acids. Linolenic fatty acids function as basic substrates for the formation of long chains of eicosapentaenoic acid (EPA) and docosahexaenoic acid (DHA). Linolenic essential fatty acids cannot be produced in the body and must be obtained from feed. After this, with the help of enzymes, they are converted into long hydrocarbon chains. The results of the analysis of fatty acid profiles in feed using fermented L. minor meal as a substitute for soybean meal was $4.37 \%$ (Table 6); thus, the excess of these fatty acids is stored as an energy source to support growth and aid in the metabolic process. The results of these studies are in agreement with the findings of Gao et al. (2011). Freshwater fish do not need longchain unsaturated fatty acids (HUFA) but require C18 n-3 fatty acids, namely linolenic acid (18: 3-n-3), with concentrations ranging from $0.5 \%$ to $1.5 \%$ in feed. Another function of linolenic fatty acids described by Gao et al. (2011) is the formation of double bonds in HUFA, EPA, and DHA, which is very important for metabolic function and the components in cell membranes.

Based on the results of this study, the survival rate of tilapia fed with fermented $L$. minor meal as a substitute for soybean meal was $94.44 \%$. This was higher than the survival rate of tilapia without the $L$. minor meal substitution, which was $88.00 \%$. This survival rate was higher than that reported by Sulawesty et al. (2014) using carp (Cyprinus carpio L.) that were not fed with L. minor, which had a survival rate of $60 \%$. However, those that were fed with L. minor had a survival rate of $70 \%$. Tilapia fed with fermented $L$. minor meal as a substitute for soybean meal exhibited a higher survival rate. The high survival rate of tilapia was caused by internal and external factors. Internal factors included feed, age, and resistance to disease, whereas external factors comprised the stocking density, disease, and water quality. Kelabora (2010) stated that an important factor affecting the growth and survival rate of fish other than feed is water quality, especially temperature. As temperature can affect the growth and appetite of fish, the temperature can affect important activities of fish, such as breathing, growth, and reproduction. High temperatures can reduce dissolved oxygen and affect fish appetite.

The best growth was for the treatment of tilapia fed with $2.5 \%$ fermented $L$. minor meal because it produced a weight gain of $33.03 \%$ and an RGR of $2.01 \%$. The results showed that feeding tilapia with fermented $L$. minor meal had a significant effect $(\mathrm{P}<0.05)$ on TFC, FUE, PER, and RGR, but did not have a significant effect $(P>0.05)$ on SR. Currently, only a few previous studies have focused on L. minor as a feed ingredient. The results of this study, which showed higher values than those reported by previous studies, will have an important impact on research 
on the use of L. minor as a feed substitution for fish, especially tilapia.

The use of fermented L. minor meal as a substitute for soybean meal was possible because tilapia is an omnivorous fish that tend to be herbivorous; consequently, it is easier for them to adapt to feed with vegetable sources. Additionally, $2.5 \%$ fermented L. minor meal can be used by farmers, thereby reducing production costs, especially for the feed.

In conclusion, the growth performance and nutritional quality of tilapia fed by fermented $L$. minor meals had been reported. Feeding of tilapia using fermented L. minor meal has a significant effect $(P<0.05)$ on total feed consumption, feed utilization efficiency, protein efficiency ratio, and relative growth rate, and had no significant effect $(P>0.05)$ on survival rate. Treatment B (the usage of $2.5 \%$ fermented L. minor meal as a substitute for soybean meal) gave the best result as the best feed formulation which can be applied for future fish aquaculture rearing.

\section{ACKNOWLEDGEMENTS}

This research was funded by Directorate of Research and Community Service, Directorate General of Research Strengthening and Development, The Ministry of Research, Technology and Higher Education of The Republic of Indonesia, the fiscal year of 2019 with grant number of 101-11/UN.7.P4.3/PP/2019.

\section{REFERENCES}

Aas TS, Grisdale-Helland B, Terjesen BF, Helland SJ. 2006a. Improved growth and nutrient utilization in Atlantic salmon (Salmo salar) fed diets containing a bacterial protein meal. Aquaculture 259: 365-376.

Aas TS, Hatlen B, Grisdale-Heland B, Terjesen BF, Bakke-McKellep AM, Helland SJ. 2006b. Effects of diets containing a bacterial protein meal on growth and feed utilization in rainbow trout (Oncorhynchus mykiss). Aquaculture 261: 357-368.

Abu E, Marzuok NM, Moustafa. 2013. Use of different Saccharomyces cerevisiae biotic form as immune modulator and growth promoter for Oreochromis niloticus challenged with some fish pathogens. Intl J Vet Sci Medic 1: 21-29.

Ajay Kumar Patra. 2015. Evaluation of the duckweed (Lemna minor) mea as partial replacement for fish meal on the growth performance of Labeo rohita (Ham.) fry. Eur J Exp Biol 5 (10): 18-23.

AOAC. 2000. Official Methods of Analysis. $17^{\text {th }}$ edition, Horwitz W. (ed), Academic Press, Washington DC, USA.

Appenroth KJ, Sree KS, Bog M, Ecker J, Seeliger C, Böhm V, Lorkowski S, Sommer K, Tolzin-Banasch WVK, Leiterer RKM, Liebisch CDG, Jahreis G. 2018. Nutritional value of the Duckweed species of the Genus Wolffia (Lemnaceae) as human food. Front Chem Crop Biol Sustain 6 (483): 1-13. DOI: 10.3389/fchem.2018.00483.

Asadi, Rad, Zakeri MM, Vahid Y, Seyed SM. 2012. Effect of dietary levels of dietary supplementation of Saccharomyces cerevisiae on growth performance, food utilization and body biochemical composition of Nile Tilapia (Oreochromis niloticus) fingerlings. J Pers Gulf. 3: 15-24.

Chakrabarti R, Clark W.D, Sharma J.G, Goswami R.K, Shrivastav A.K Tocher D.R, 2018. Mass production of Lemna minor and its amino acid and fatty acid profiles. Front Chem 6: 479.

Chakrabarti R, Clark WD, Sharma JG, Goswami RK, Shrivastav AK, Shrivastav AK, Tocher DR. 2018. Mass production of Lemna minor and its amino acid and fatty acid profiles. Front Chem Crop Biol Sustain 6 (479): 1-16. DOI: 10.3389/fchem.2018.00479
De Silva S.S. 1987 Finfish Nutritional Research in Asia. Proceeding of The Second Asian Fish Nutrition Network Meeting. Heinemann, Singapore.

del Carmen Flores-Miranda M, Luna-González A, Cortés-Espinosa D.V, Álvarez-Ruiz P, Cortés-Jacinto E, Valdez-González F.J, EscamillaMontes R, González-Ocampo H.A. 2015. Effects of diets with fermented duckweed (Lemna sp.) on growth performance and gene expression in the Pacific white shrimp, Litopenaeus vannamei. Aquac Intl 23 (2): 547-561

Dewanji A. 1993. Amino acid composition of leaf protein extracted from some aquatic weeds. J Agric Food Chem 41: 1232-1236.

Gao W, Liu, Tian, Mai, Liang, Yang, Huai, Luo. 2011. Protein sparing capability of dietary lipid in herbivorous and omnivorous freshwater finfish: A comparative case study on Ctenopharyngodon idella and Oreochromis niloticus. J Aqua Nut 17: 2-12.

Handajani H. 2011. The content of heavy metals in aquatic and fish samples in Situbondo waters. Jurnal Gamma 6 (2): 18-24. [Indonesian]

Herawati V.E, Hutabarat J, Radjasa O.K. 2014. Nutritional Content of Artemia sp. Fed with Chaetoceros calcitrans and Skeletonema costatum. Hayati J Biosci 21 (4): 166-172.

Herawati VE, Hutabarat J, Pinandoyo, Radjasa OK. 2015. Growth and survival rate of tilapia (O. niloticus) larvae fed by Daphnia magna cultured with organic fertilizer resulted from probiotic bacteria fermentation. Hayati J Biosci 22: 169-173.

Hossain M.A, Jauncey K. 1990. Substitution of fish meal by oilseed meals in various combinations in the diet of common carp (Cyprinus carpio). Malaysian Appl Biol 19 (2): 1-12.

Ivaylo Sirakov, Katya Velichkova. 2018. The influence of aquaponically grown Duckweed (Lemna minuta Kunth) used for composition of sustainable diets on hydrochemical and technological parameters in Carp (Cyprinus carpio L.). Turkish J Fish Aquat Sci 18 (9): 10371044.

Kelabora DM. 2010. Effect of temperature on survival and growth of carp larvae (Cyprinus carpio). Terubuk Fish Period J 38 (1): 71-81.

Khasani I. 2013 Attractants in fish feed: fish types, functions, and responses. J Aquacult Media 8 (2): 127-133.

Nwachi OF. 2013. An overview of the importance of probiotics in aquaculture. J Fish Aquat Sci 8 (1): 30-32.

Olaniyi CO, Oladunjoye IO. 2012. Replacement value of duckweed (Lemna minor) in Nile tilapia (Oreochromis niloticus) diet. Transnatl J Sci Technol 2 (9): 54-62.

Ovie SO, Eze SS. 2013. Lysine requirement and its effect on body composition of Oreochromis niloticus fingerlings. J Fish Aquat Sci 8 (1): 94-100

Paul M, Barman AC, Siddque MF, Bhadra A, Rahman MS. 2013. Effect of use of Duckweed Powder as a fish feed on polyculture of carps. J Environ Sci Nat Resour 6 (2): 213-216.

Pinandoyo, Hutabarat J, Darmanto YS, Radjasa OK, Herawati VE. 2019. Growth and nutrient value of tilapia (Oreochromis niloticus) fed with Lemna minor meal based on different fermentation time. AACL Bioflux 12 (1): 191-200.

Pramana A, Agustono A, Nurhajati T. 2019. Addition of lysine to commercial feed on the growth rate, feed conversion ratio and feed efficiency of giant prawn (Macrobrachium rosenbergii). J Aquac Fish Health 7 (1): 18-24.

Santiago, C.B, Lovell, R.T. 1988. Amino acid requirement for growth of nile tilapia. The Journal of Nutrition. 118: 1.540-1.546.

Sogbesan OA, Onoja CF, Adedeji HA, Idowu TA. 2015. Utilization of treated duckweed meal (Lemna pausicostata) as plant protein supplement in African mud catfish (Clarias gariepinus) juvenile diets. Fish Aquac J 6: 4. DOI: 10.4172/2150-3508.1000141.

Solomon SG, Okomoda VT. 2012. Growth performance of Oreochromis niloticus fed duckweed (Lemna minor) based diets in outdoor hapas. Intl J Res Fish Aquacult 2 (4): 61-65.

Srirangam GM. 2016. Effect of partial replacement of fish meal with duckweed (Lemna minor), and soybean meal on the growth performance of Ctenopharyngodon idella (grass carp). Intl J Fish Aquat Stud 4 (6): 133-137.

Sulawesty F, Chrismadha T, Mulyana E. 2014. Growth rate of carp (Cyprinus carpio L.) feed with fresh (Lemna perpusilla Torr.) on closed pond. J Trop Inland Waters Indon 21 (2): 177-184.

Tacon AEJ. 1987. The nutrition and feeding formed fish and shrimp. A Training Manual Food and Agriculture of United Nations. Brazilling, Brazil. 
Talukdar MZH, Shahjahan MS, Rahman. 2012. Suitability of duckweed (Lemna minor) as feed for fish in polyculture system. Intl J Agric Res Innov Tech 2 (1): 42-46.

Valverde S, Liorens M, Vidal AT, Rodriguez CE, Gairin JL, Domingues PM, Rodriguez GB. 2013. Amino acids composition and protein quality evaluation of microalgae and meals for feed formulations in Cephalopods. J Aquacult Intl 21: 413-33.

Virnanto LA, Rachmawati D, Samidjan I. 2016. Utilization of Azolla (Azolla microphylla) fermented flour as artificial feed mixtures to increase growth and survival of gurame fish (Osphronemus gouramy). J Aquacult Manag Technol 5 (1): 1-7.

Wilson RP. 1982. Energy relationships in catfish diets. In: Stickney RR, Lovell RT (eds.). Nutrition and Feeding of Channel Catfish. Southern Cooperative Series Bulletin 2: 218, Auburn University, Alabama.

Yilmaz E, Akyurt I, Gunal G. 2004. Use of duckweed (Lemna minor) as a protein feedstuff in practical diets common carp (Cyprinus carpio Fry). Turkish Fish Aquat Sci 4: 105-109. 